\title{
Sundays with Roque: A Tale of Friendship and Companionship
}

Tomas G. Rosario, Jr. ${ }^{1}$

\begin{abstract}
Sundays with Roque" is partly narrative, mainly reflective essay patterned after the best-selling memoir Tuesdays with Morrie. Like Tuesdays with Morrie, which tells the inspiring story of the relationship between writer Mitch Albom and his professor Morrie Schwartz, this narrative-reflective essay is about the equally inspirational bond between Leovino Garcia and his former professor Fr. Roque Ferriols, S.J. Their relation is a tale of friendship and companionship that manifest extraordinary commitment, fidelity, and sacrifices from both parties in their mutual care and dynamic love for one another. What is most noteworthy, however, in "Sundays with Roque," is that it serves as a call, even an appeal, to the present generation to recognize the principal value of companionship in caring for our elderly family members and our friends.
\end{abstract}

Keywords: Aristotle, Aquinas, Ferriols, Garcia

7 uesdays with Morrie $^{2}$ is an unusually inspirational memoir which became an international best-seller when it was published in 1997. I was given a copy of this book as a fitting birthday gift in the year 2000 by a former student from Davao city. She had apparently looked up to me not only as her teacher but also as her guardian because I took care of her as a resident student of Eliazo Hall for four years. Perhaps, she had viewed her relation with me and my influence on her during her four-year academic life

${ }^{1}$ Tomas G. Rosario, Jr. was a full professor in the Department of Philosophy at the Ateneo de Manila University. He finished his PhD in Philosophy from the University of Santo Tomas in 1990 and did postdoctoral studies at the Katholieke Universiteit Leuven in Belgium in 1994. Known for his translations of the Summa of Thomas Aquinas from Latin to Filipino, he also specialized on the thoughts of Richard Rorty. He was 67 years old when he died last 6 December 2017. The editor of this essay is Mark Joseph T. Calano, Coordinator for Research and Creative Works of the School of Humanities and Assistant Professor of Philosophy at the Ateneo de Manila University. Inc., 1997).

2 Mitch Albom, Tuesdays with Morrie (New York: Doubleday Dell Publishing Group,

(c) 2018 Tomas G. Rosario

https://www.kritike.org/journal/issue 23/rosario december2018.pdf

ISSN 1908-7330

(cc) $\mathrm{BY}-\mathrm{NC}-\mathrm{ND}$ 


\section{SUNDAYS WITH ROQUE}

in Ateneo as a relatively noteworthy instance of the more ennobling bond between the two main figures in the memoir: author Mitch Albom and Morrie Schwartz, a retired university professor suffering from a serious type of sclerosis.

The book is a chronicle of Mitch Albom's Tuesday visits to his very ill former mentor. These visits have been highlighted by discussions on fundamentally human issues, such as marriage, family, feeling sorry for oneself, regrets, emotions, fear of aging, forgiveness, giving love, and, of course, death. But more than an academic nostalgia, this unexpected reunion between a favorite student and a greatly admired teacher has turned out to be a rediscovery of something truly noble in the personality not only of the forgotten teacher but also of the forgetful and ambitious former student. Their Tuesday dialogues have been opportunities to be reflective on two subjects that Mitch finally realized to be the most crucial in life but which he failed to seriously think about when Morrie raised them in his classes, namely, "being human" and "relating to others." ${ }^{3}$ Mitch recalls in the book that these topics sounded strange and distant when he was a young university student.

As such, the Tuesday visits have provided Mitch with a now-ornever chance to relearn about being human from Morrie. The book thus abounds with words of philosophical wisdom. On the fourth Tuesday visit, for instance, when they dwelt on death, Morrie points out to Mitch: the "imminence of death makes us see our lives in a radically different way." 4 Once, he evokes Socrates as when he gave a paradoxical lesson: "Learn how to die, and you learn how to live." 5 In every conversation with Morrie, Mitch learns something new. In one conversation, he realizes that Morrie had been aware of his ambitious disposition and conduct. ${ }^{6}$ There is no doubt that Morrie was deeply concerned then about Mitch's preoccupation with what he called the "egotistical concerns" 7 of the $20^{\text {th }}$-century American culture, characterized by what we learned from Marcel as the goods of having, such as career, money, owning a luxurious house in a rich village, a new car, and the like. If Morrie has frankly called Mitch's attention about the latter's ambitiousness, it is only because he is genuinely concerned for his wellbeing. A particularly memorable wisdom from Morrie is his conviction that "the most important thing in life is to learn how to give out love, and to let it come in" 8 which demonstrates that he viewed "being human" as centrally constituted by a loving communion with fellowmen. His idea of giving out

\footnotetext{
${ }^{3}$ Ibid., 17.

${ }^{4}$ Ibid., 83.

${ }^{5}$ Ibid.

${ }^{6}$ Ibid.

${ }^{7}$ Ibid, 64 .

8 Ibid., 52.
}

(C) 2018 Tomas G. Rosario

https://www.kritike.org/journal/issue 23/rosario december2018.pdf ISSN 1908-7330

(c) BY-NC-ND 
love need not entail great sacrifices as it may just be ordinary gestures like allotting someone time to provide companionship and engage in storytelling. ${ }^{9}$ It is probably because of this deep insight on love that Morrie finds hope that his death does not entail separation from Mitch insofar as Morrie's love continues to dwell in his heart ${ }^{10}$ and energizes him to serve other people and his community. ${ }^{11}$ It is this love, i.e., the love of people who patiently care for him, that protected and strengthened Morrie against self-pity and despair. ${ }^{12} \mathrm{He}$ displayed great hope in spite of his daily sufferings and of his knowledge of the incurable character of his illness.

From this brief narrative of Tuesdays with Morrie, which features insightful dialogues between the teacher and his former student, I am reminded of another true story of exemplary bond between a Jesuit priest, Roque Ferriols, and his former student, Leovino Garcia. Based on Garcia's own account, Ferriols had assumed the task of serving as his protective guardian and mentor since he started his college education up to the time that he gained the honor of becoming an Ateneo faculty member. Ferriols never relented in the succeeding years, not only to guide and support Garcia in the performance of his tasks and in the realization of the university vision when he became an administrator at the Ateneo de Manila University, but also to vigorously defend him when confronted with detractive criticisms of his academic leadership by certain faculty members and even by other university administrators.

Now, what I have observed for more than twenty years and continue to witness today is the faithful and patient devotion of Garcia not only to look after the physical wellbeing of Ferriols in view of the latter's old age, but also, and especially, to spend quality time with him. As we have seen above, this spending of quality time is, according to Morrie, one of the noble gestures of loving commitment. But perhaps what makes Garcia's tireless caring attention for Ferriols all the more praiseworthy and exemplary is his unchangeable and unconditional dedication to lovingly serve his mentor and spiritual father in spite of the widely known volatile temperament of the latter. I, myself, have witnessed the outburst of the fiery anger of Ferriols on several occasions when I was his student pursuing a master's degree in Philosophy and during the initial years of my teaching career in Ateneo. But it will be an unjust narrative of my personal encounters with Ferriols if I do not take note of my experiences of the gentle, warm, and generous aspects of his personality.

\footnotetext{
${ }^{9}$ Ibid., 126.

10 Ibid., 174.

${ }^{11}$ Ibid., 127.

${ }^{12}$ Ibid., 36.
} 


\section{SUNDAYS WITH ROQUE}

Ferriols's deteriorating physical health necessitated the reduction of his teaching load and his transfer to the infirmary area of the Loyola House of Studies where a 24-hour immediate attention is provided by the medical staff. Yet, in spite of this professional medical service available to Ferriols, Garcia has reserved Sunday afternoons to visit and to be with him. It was on one Sunday afternoon that I was able to accompany Garcia in his selfprescribed schedule of visits and noticed then that Ferriols has lost much energy of mobility, yet he obviously has the fortitude to be as active as he could be.

Perhaps, if one were to adhere to Marcel's nonrational mode of thinking, one would find that there is a mysterious way by which Ferriols draws strength from his regular communion with Garcia. It is, in fact, unusual that health experts do claim, on the basis of their latest studies, that social gatherings or the time spent relaxing or chatting with friends have been found to be a major factor in minimizing, if not preventing, ailments related to the heart. What we see in this claim is a clear reliance on the principle of causality, which is under the purview of rational justification, in the scientific effort to articulate the abovementioned established connection between gregariousness and one's wellbeing.

Our main interest, however, in adopting Garcia's Sunday moments with Ferriols as an appropriate model of companionship, is to try to explore the values and virtues which can be drawn from these visits of companionship and which, upon reflection, could be shown to be constitutive of moral wisdom. If there are lasting lessons of relationships that we could gain from this narrative, then, "Sundays with Roque" deserves to be considered as an inspiring story.

We may begin with companionship itself. In his treatise on happiness, Thomas Aquinas has considered societas amicorum, ${ }^{13}$ or the companionship of friends, as one of the essential elements of legitimate happiness in our earthly life. Consider the following justification:

If we speak of present-life happiness ... then the happy man must have friends. It is not that he makes use of them ... but that he needs them in order that he may act well, namely, that he may do them good, that he may take delight in seeing them do good, and also that they may help him in his good works, and also that they may

13 Thomas Aquinas, Summa Theologica of St. Thomas, trans. by Fathers of the English Dominican Province (New York: Benziger Brothers, Inc., 1947), I-II.4.8. Hereafter cited as Summa Theologica.

(c) 2018 Tomas G. Rosario

https://www.kritike.org/journal/issue 23/rosario december2018.pdf

ISSN 1908-7330

(c) BY-NC-ND 
help him in his good works, for he needs their support in both the active and contemplative life. ${ }^{14}$

St. Thomas himself acknowledges in the same passage his reliance on the teaching of Aristotle regarding the vital role of the companionship of friends in having a good and happy life. ${ }^{15}$ This acknowledgement of the saint leads us, then, to Aristotle's treatise on friendship which could help us in the understanding of the abovementioned passage and in the articulation of the Sunday companionship of Garcia with Ferriols.

First of all, Aristotelian scholars should be familiar with the teaching of Aristotle that friendship is a virtue and that it is indispensable in having a good life. ${ }^{16}$ Now, what appears to be central to his conception of friendship is that it is none other than mutual goodwill. ${ }^{17}$ This position, in fact, implies his conviction that we should not consider someone as a friend unless we desire what is good for his own sake. ${ }^{18}$ But, employing the rational tool of distinction which St. Thomas may have inherited from Aristotle, the latter clarified that goodwill should not be confused with friendship since he deemed it essential to the notion of friendship that one's goodwill should be reciprocated by the beneficiary. We may conclude from this definite conception of friendship that two individuals can be considered as friends only if they seek respectively what is truly good for one another. It should be added, however, that Aristotle should also mean in his essential conception of friendship that the mutual goodwill should be active and dynamic in character. Goodwill must involve energetic effort to attain the desired good of the beloved.

What we have seen so far as the chief teaching of Aristotle on friendship is that it signifies mutual goodwill such that the goal of goodwill is none other than the true good of the beloved. It is, in this sense, that friendship is essentially associated with what is good in a dual sense, namely, the goodwill of the benevolent person and the wellbeing of the beloved.

Moreover, we may highlight another relevant insight of Aristotle on friendship: that "... loving seems to be the characteristic virtue of friend...." 19 This is tantamount to an affirmation that friendship is a relationship of love so that the other person in the relation of friendship is someone who is

${ }^{14}$ Ibid.

${ }^{15}$ Aristotle initially observed that friends "... are thought the greatest of external goods" [Aristotle, Nicomachean Ethics, in The Basic Works of Aristotle, ed. by Richard McKeon (New York: Random House, 1941), IX.9.1169b10]. Then in reference to the 'happy man,' he declared that "...it is better to spend his days with friends and good men than with strangers or any chance persons. Therefore, the happy man needs friends." [Ibid., IX.9.1169b20.].

${ }^{16}$ Ibid., VIII.1.1155a5.

17 Ibid., VIII.2.1155b30-1156a5.

${ }^{18}$ Ibid., VIII.2.1155b30.

${ }^{19}$ Ibid., VIII.7.1159a35. 


\section{SUNDAYS WITH ROQUE}

beloved. ${ }^{20}$ Aristotle did not mean, however, that the beloved refers to any family member, or to any relative, or to an individual who is the object of one's romantic affection. I do not think that Aristotle has a parochial conception of the beloved other in the relation of friendship. In fact, it was also his clear teaching that the object of one's goodwill is someone who "has been found lovable." ${ }^{21}$ If we ask what, for him, constitutes the loveableness of both parties in friendship, Aristotle was also definite in his reply that it is "in virtue of their goodness." 22 In other words, good men are loveable because they are good or morally upright.

Now, Aristotle has considered the friendship of good men as the true and perfect form of friendship. ${ }^{23}$ Since the persons involved in this friendship are men of goodwill, their friendly companionship will endure for as long as both of them continue also to be good and righteous. ${ }^{24}$ But, if true friendship is exclusively exemplified by men of goodwill, this immediately impresses on us that most men are not engaged in honorable friendship due to self-serving interests. Aristotle himself admitted that the friendship of good men is uncommon, since, although this is a questionable view, men of virtue are very few in the society. ${ }^{25}$ But what could serve as a positive rejoinder to the abovementioned admission that seemed to erode his preference for the friendship of good men is his own claim that true friendship takes time to develop, but it is attainable. In other words, since Aristotle has viewed friendship as one of the moral virtues, ${ }^{26}$ imperfect forms of friendship like friendship of utility or friendship of pleasure could undergo a metamorphosis towards the realization of the perfect friendship of men of goodwill.

Finally, we must not fail to point out that friendship entails equality ${ }^{27}$ even in inequality. ${ }^{28}$ First of all, friends are equal in terms of the good that they desire and they obtain reciprocally. ${ }^{29}$ Aristotle made this specifically clear with his teaching that it is in the case of perfect friendship wherein there

\footnotetext{
${ }^{20}$ In relation to this, St. Thomas himself held the view that "...love consists chiefly in this, that the 'lover desires the good of the beloved'." Thomas Aquinas, Summa contra Gentiles, trans. by Brian Davies (New York: Oxford University Press, 2016), III.90. See also Aquinas, Summa Theologica, I.20.1-2.

${ }^{21}$ Aristotle, Nicomachean Ethics, VIII.3.1156b25-30.

22 Ibid., VIII.4.1157b35.

${ }^{23}$ Aristotle referred to other forms of friendship such as the friendship of utility and the friendship of pleasure, both of which he considered as transient and vulnerable to dissolution. Ibid., VIII.3.1156a5-20.

${ }^{24}$ Ibid., VIII.3.1156b10.

${ }^{25}$ Ibid., VIII.3.1156b25.

${ }^{26}$ Ibid., VIII1.1155a5.

${ }^{27}$ Ibid., VIII5.1157b35, 1158b.

${ }^{28}$ Ibid., VIII8.1159b5.

${ }^{29}$ Ibid., VIII6.1158a5.

(c) 2018 Tomas G. Rosario

https://www.kritike.org/journal/issue 23/rosario december2018.pdf

ISSN 1908-7330
}

(cc) BY-NC-ND 
is "an equal return in goodwill and in pleasantness." 30 This declaration shows that Aristotle has not referred to physical factors like age, economic status, or position of influence in speaking of equality in friendship. Now, in speaking of equality in mutual goodwill and in pleasant companionship, he impressed on us the view that goodwill is the equalizing factor in friendship. This means that inequality or difference in age or in socio-economic status is overcome due to the goodwill, in particular, of the partner in friendship who is either more advanced in age or who occupies a position of superiority or authority in the society. It is, in fact, our common experience that goodwill easily stimulates mutual goodwill and, in itself, is the source of tranquil delight associated with a high level of happiness. In this sense, then, we could say that goodwill is the primary principle which undermines all barriers to friendship and which serves also as probably the most effective cause of communion or of durable and nobly pleasant companionship.

Against the background of our consultation on Aristotle's treatise on friendship, we could notice, if we go back to the passage on companionship of friends drawn from St. Thomas's treatise on happiness, that it is focused also on what is good in speaking of the happy man's need for friends. But what is remarkably significant is the consonance of the two thinkers' conception of friendship in terms of the good: just as Aristotle has spoken of friendship as the virtue of willing the good of the beloved friend, St. Thomas has seen it as an opportunity for mutual support or cooperation to do good deeds. Now, this fundamental concord between the Aristotelian and Thomistic theories of friendship could help in our reflection on the extraordinary story of Garcia's Sundays with Roque.

At this stage of our reflection, we may now say that the relation between Garcia and Ferriols falls under what Aristotle described as the friendship of good men. It might be the case, however, that Garcia does not relate himself as a friend, in the common sense of this word, to Ferriols, but that he esteems highly and reveres greatly the latter as his guardian and adviser, as the source of wise counsels, principles, and life lessons. Nonetheless, it is undeniable that it is the principle of goodwill that truly governs their relationship. Garcia himself has confided, in many occasions, to his close friends and even to his colleagues, the demonstration of his goodwill in terms of the unconditional care and the many sacrifices of Ferriols not only when he started his teaching career in Ateneo, but also during the many difficult years when he occupied a major administrative position in the university as he contributed to the promotion of its academic mission and goals.

${ }^{30}$ Ibid., VIII5.1157b35.

(c) 2018 Tomas G. Rosario

https://www.kritike.org/journal/issue 23/rosario december2018.pdf

ISSN 1908-7330

(cc) BY-NC-ND 


\section{SUNDAYS WITH ROQUE}

Garcia's Sundays with Roque might be viewed as an instance of the Filipino value of utang na loob. But, if the sociological analysis of utang na loob as part of the Filipino social culture is valid, then it could be abused to manipulate and even enslave someone with a debt of gratitude. ${ }^{31}$ This Filipino value, then, must be reexamined in order to explore and discover its possibly principal character as a moral value. To assist in attaining this goal, let us consult the pertinent teachings of Dietrich von Hildebrand. According to him, when I am grateful to someone, my gratitude is indicative of two things: the first is that an objective good for me as a human person is the result of the good action of the other person to whom I am grateful; the second is that "gratitude also refers to the morally noble attitude of my benefactor which manifests itself in his bestowing the benefit on me." 32 What we see in these teachings of Hildebrand is that when one is grateful, the response of gratitude is directed to and is an acknowledgement of the intentio benevolentiae ${ }^{33}$ or the goodwill of the individual who has done a good deed which generates what is truly good for him as an individual human person. He was also categorical in his affirmation that the benevolent intention or goodwill is directed to the person or persons we love. ${ }^{34}$ Furthermore, gratitude necessarily presupposes the value of moral goodness of the doer of the good act.

What strikes our interest in these teachings of Hildebrand is that they confirm at least one of the main teachings of Aristotle, namely, that goodwill is directed to the person we love. But what is more significant is his position that gratitude is not only a recognition by the grateful person of the true good which he has received, but also of the morally good intention of the doer of the good act. This teaching of Hildebrand is crucial, for it means that the Filipino value response of utang na loob, if we go beyond the sociological view, has a meaning that perhaps properly pertains to the sphere of morality. Following Hildebrand's doctrine on the relation of gratitude to the intentio benevolentiae of the doer of the good act, utang na loob should signify a moral debt-if we follow St. Thomas, ${ }^{35}$ - to the goodwill of the benevolent agent. But this moral indebtedness is neither manipulative nor enslaving, since, if it could be either, it would contradict the very principle of goodwill. In other words, it is thoroughly inconsistent with one's benevolent intention for the

\footnotetext{
${ }^{31}$ Evelyn Miranda-Feliciano, Filipino Values and our Christian Faith (Mandaluyong: OMF Literature Inc., 1990), 70.

${ }^{32}$ Dietrich von Hildebrand, Christian Ethics (New York: David McKay Company, Inc., 1953), 50 .

${ }^{33}$ Ibid., 59.

${ }^{34}$ Ibid.

${ }^{35}$ St. Thomas clearly taught that it is in accordance with justice that as a beneficiary of good act one should know "... gratitude, whereby a debt is paid to benefactors ...." Aquinas, Summa Theologica, I-II.60.3.

(C) 2018 Tomas G. Rosario

https://www.kritike.org/journal/issue 23/rosario december2018.pdf

ISSN 1908-7330
}

(cc) BY-NC-ND 
beloved to bind him or her to one's demands and wishes through regular reminders of the big favors one has bestowed upon him or her.

Following this ethical study, the goodwill is attributed to a morally upright agent whose intention for doing a good act for another person is not tainted by self-gratifying actual result or future benefit for the said doer of the act. It is in the moral sense then that we could consider Garcia's Sundays with Roque as an act of utang na loob.

It is unfair, however, to view Garcia's utang na loob to Ferriols as nothing but a demonstration of what St. Thomas has called the moral obligation to be grateful. For, as we have already noted above, Garcia has quietly demonstrated bountiful concern and patient commitment to care for Ferriols for probably more than three decades by now. We should turn instead to St. Thomas' treatise on God's love in order to articulate Garcia's morally relevant affection for Ferriols. We learn in this treatise that, "to love a person is to will good for that person," 36 which we notice to be essentially similar to the position of Aristotle. Now, just as it is the principle of goodwill that moved Ferriols when he attended to and looked after the personal and professional welfare of Garcia, especially during the adjustment years of his teaching career, the same principle continues to animate Garcia's indefatigable attentive visits to Ferriols. It is very significant to note at this stage of our reflection that Garcia's devotion to care for Ferriols is a clear proof that goodwill generates mutual goodwill.

Hence, we may make the definitive claim that it is at the level of mutual goodwill, or what St. Thomas referred to as the superior love of friendship, ${ }^{37}$ which characterizes the relation of Ferriols and Garcia, which is undoubtedly similar to the relation of mutual loving care between Morrie and his student Mitch.

Now, we may initially note as a moral lesson in life, our wisdom story that this extraordinary bond of mutual goodwill between Ferriols and Garcia is a forceful reminder to promote what is commonly acknowledged as a value ordinarily associated with family life: this is none other than the caring for the elderly. It is truly very unfortunate that in a widely secularized society today characterized by mobility, anonymity, and obsession with success, the care for the elderly is either relegated to institutions like "Home for the Aged," or, if they stay with their own family, they do not receive adequate attention, especially the care which is vital to their psychological and social wellbeing. It is, I believe, an eminent testimony of magnanimous self-giving for Garcia to take upon himself the loving commitment to personally attend to Ferriols, although the latter belongs to a religious community whose

${ }^{36}$ Ibid., I-II.20.1, ad 3. See also I-II.20.2 and I-II.20.3.

${ }^{37}$ Ibid., I-II.20.2, ad 3.

(c) 2018 Tomas G. Rosario

https://www.kritike.org/journal/issue 23/rosario december2018.pdf

ISSN 1908-7330

(cc) BY-NC-ND 


\section{SUNDAYS WITH ROQUE}

members are supposed to be mandated by the rules of their religious life to cultivate the sort of companionship appropriate to a religious society inspired by Jesus Christ.

Moreover, this true story of mutual goodwill is an extraordinary affirmation of what was claimed in Tuesdays with Morrie as the most important thing in life, namely, to give out love and to be open to receive it in spite of the fact that the abovementioned individuals involved do not have family ties. This indicates that there is a truly noble and great reason or principle transcending the blood relationship which is the common basis for bestowing care and support for the elderly or for someone close to us. We already referred to this noble reason and moral principle as the principle of goodwill. Our consultation of the related teachings of Aristotle, St. Thomas, and Hildebrand helped us see that it is this principle which mutually motivated Ferriols and Garcia to be dedicated in their active concern for each other's welfare.

It was the opinion of Aristotle that it is rare to find good men whom he considered as the only ones capable of cultivating mutual goodwill. But, if his skepticism on the promotion of goodwill among men has any plausibility, it would mean that the Ferriols-Garcia story of friendship of good men should be considered as an isolated case. Aristotle, however, may have overstated his negative perception of the possible expansion of mutual goodwill among members of the society for we may raise, at least, my personal experiences of noble friendship and companionship with former dorm scholars from various parts of the country who are still in regular contact with me to express our relative opposition to Aristotle's position. In fact, I could still recall Garcia's advice to me, when I was designated as Director of the Residence Halls through his recommendation: that is, not to fail to take care of dorm scholars for, one day, they will reciprocate my goodwill. And I must not fail to add another corroborating personal experience, for it shows that the mutual goodwill and companionship between Ferriols and Garcia could be a positively contagious and self-propagating example, that is, that Garcia has expanded his goodwill to me: he unconditionally assisted me towards the promotion of my teaching career and he has also provided me with the opportunities to rise from being an unknown Ateneo faculty to being acknowledged and honored as one of the best teachers of the university.

These evidences lead us now to the last point. Finally, and most of all, this wisdom story, "Sundays with Roque," in hindsight, serves to corroborate what I have envisioned as probably the principal categorical imperative of a philosophy teacher: that he/she is more a guardian of goodwill than a guardian of philosophically sanctioned truth. As a guardian of goodwill, I am convinced that Ferriols, Garcia, myself, and the new generation of philosophy teachers could contribute to the vision of building

(c) 2018 Tomas G. Rosario

https://www.kritike.org/journal/issue 23/rosario december2018.pdf

ISSN 1908-7330

(c) $)$ BY-NC-ND 
a solidarity of mutual goodwill, at least, with our students and with one another.

Department of Philosophy, Ateneo de Manila University, Philippines

\section{References}

Albom, Mitch, Tuesdays with Morrie (New York: Doubleday Dell Publishing Group, Inc., 1997).

Aristotle, Nicomachean Ethics, in The Basic Works of Aristotle, ed. by Richard McKeon (New York: Random House, 1941).

Aquinas, Thomas, Summa contra Gentiles, trans. by Brian Davies (New York: Oxford University Press, 2016).

Summa Theologica of St. Thomas, trans. by Fathers of the English Dominican Province (New York: Benziger Brothers, Inc., 1947).

von Hildebrand, Dietrich, Christian Ethics (New York: David McKay Company, 1953).

Miranda-Feliciano, Evelyn, Filipino Values and our Christian Faith, (Mandaluyong: OMF Literature Inc., 1990). 